\title{
KONFLIK SOSIAL PADA TOKOH UTAMA DALAM NOVEL I AM MALALA KARYA CHRISTINA LAMB (Suatu Penelitian Sosiologi Sastra)
}

\author{
ANIS SETIYANTI \\ PascaSarjana Universitas Negeri Jakarta \\ anis.setiyanti@gmail.com
}

\begin{abstract}
This study aims to reveal information about the forms, causes, and the completion of social conflicts described by the author in the novel "I am Malala" by Christina Lamb. Research has been conducted in Jakarta from July 2014 through the month of August 2015. This study uses descriptive qualitative content analysis method using sociological approach literature both of the focus of research, ask questions, data collection, verification of the validity of the data, analyzing, interpreting, find, verify, and concluded. The results show that this novel contains positive values that can be used as a reference to examine the contents of the novel literature and attached to public life, although it contains about social conflict. Based on the research results, it is suggested that the novel "I am Malala," by Christina Lamb could be a medium in teaching social values and working to tackle the problem of social conflict on students happens in literary learning process.
\end{abstract}

\section{Keywords: Novel, Social Conflict, main figure and Sociologi Literary.}

\begin{abstract}
Abstrak: Penelitian ini bertujuan untuk mengungkapkan berbagai informasi tentang bentuk-bentuk, penyebab, dan penyelesaian terhadap konflik sosial yang dijelaskan oleh penulis dalam novel "I Am Malala," Karya Christina Lamb. Penelitian telah dilakukan di Jakarta dari bulan Juli 2014 sampai dengan bulan Agustus 2015. Penelitian ini menggunakan metode kualitatif deskriptif dengan metode analisis isi menggunakan pendekatan sosiologi sastra baik dari fokus penelitian, mengajukan pertanyaan, pengumpulan data, verifikasi keabsahan data, menganalisis, menafsirkan, menemukan, memverifikasi, dan menyimpulkan. Hasil penelitian menunjukkan bahwa novel ini mengandung nilai-nilai positif yang dapat dijadikan acuan untuk menelaah sastra dan isi novel tersebut lekat dengan kehidupan masyarakat, walaupun berisi tentang konflik sosial. Berdasarkan hasil penelitian, disarankan bahwa novel "I am Malala," karya Christina Lamb bisa menjadi media dalam mengajar nilai sosial dan dapat berupaya menangani masalahkonflik sosial pada anak didik yang terjadi dalam proses pembelajaran kesusastraan.
\end{abstract}

Kata Kunci: Novel, Konflik Sosial, Tokoh Utama, dan Sosiologi Sastra.

\section{A. PENDAhuluan}

Di dalam sebuah karya sastra, termasuk novel, dapat diungkapkan penggambaran yang bermanfaat dan menarik, berkaitan dengan manusia serta kehidupannya, seperti perihal konflik sosial pada seseorang. Novel sebagai salah satu bentuk karya sastra prosa fiksi lahir berdasarkan daya imajinasi, pengalaman, pengamatan, serta pemikiran 
pengarang terhadap kehidupan manusia. Pengarang novel dapat menciptakan berbagai penggambaran konflik yang menarik melalui tokoh utama dalam novelnya.

Dalam isi sebuah novel dapat ditemukan penggambaran konflik pada manusia, yang ditampilkan melalui tokoh utama di dalam novel. Adanya konflik pada tokoh utama di dalam sebuah novel, menarik peneliti untuk menganalisis hal tersebut dengan lebih mendalam, mengingat penelahaan novel untuk para pembelajar sastra belum mendalam hingga ke ranah abnormalitas kejiwaan, terutama tentang konflik yang terjadi pada remaja.

Pengajaran sastra merupakan proses interaksional untuk memperoleh makna melalui karya sastra dan membangun pengetahuan tentang sastra. Model-model pengajaran sastra untuk mencapai tujuan ini beranjak dari teori, desain, praktik, dan evaluasi. Dalam bentuk pakem, pengetahuan sastra adalah ilmu sastra yang terdiri dari teori sastra, sejarah sastra, dan kritik sastra.

Purwo (1991:61) mengatakan bahwa pembelajaran sastra bertujuan mengembangkan kepekaan siswa terhadap nilai-nilai inderawi, nilai akali, nilai agama, dan nilai sosial, secara sendirisendiri atau gabungan dari keseluruhannya sebagaimana tercermin dalam karya sastra. Jika nilai-nilai moral seperti tercermin dalam karya sastra dipahami, dihayati lalu diterapkan dalam kehidupan pelajar sehari-hari, tidak tertutup kemungkinan pelajar sebagai generasi muda bangsa akan memiliki sikap dan mental positif.

Salah satu novel yang memuat unsur konflik sosial adalah novel I Am Malala karya Christina Lamb. Novel tersebut menceritakan tentang kehidupan seorang gadis bernama Malala yang berjuang di jalan pendidikan dengan memperjuangkan hak-hak anak perempuan untuk mendapatkan kehidupan yang layak khususnya di dunia pendidikan. Adapun konflik yang diwakilkan oleh tokoh utama, Malala, dilatarbelakangi oleh diskriminasi terhadap kaum perempuan untuk mendapatkan perlakuan yang sama dengan laki-laki dalam kehidupan nyata terutama dalam mendapatkan hak pendidikan yang layak.

Di dalam novel I Am Malala karya Christina Lamb, terdapat poin-poin menarik yang menguatkan pemikiran peneliti bahwa novel tersebut layak untuk diteliti dengan tinjauan sosiologi sastra, Adapun perihal tersebut tersusun dari beberapa alasan penting. Pertama, di dalam pembelajaran sastra, penelitian yang mengacu pada sosiologi sastra dengan menggunakan novel masih minim dilakukan. Kedua, di dalam novel I Am 
Malala karya Christina Lamb terdapat fenomena-fenomena konflik sosial berdasarkan pengamatan peneliti setelah membaca novel tersebut. Ketiga, novel I Am Malala karya Christina Lamb mengandung unsur sosiologi, sehingga untuk menelaah novel tersebut menggunakan sosiologi sastra sebagai tinjauannya. Keempat, novel I Am Malala karya Christina Lamb menampilkan konflik-konflik yang rinci melalui tokohtokoh di dalamnya. Kelima, novel I Am Malala karya Christina Lamb tetap menggambarkan hal-hal positif yang ditampilkan oleh tokoh utama, Malala, melalui bakat yang dimilikinya serta kepribadiannya. Keenam, novel I Am Malala karya Christina Lamb termasuk novel Best Seller, dan meraih penghargaan novel terbaik dari national book award, juga menjadi Best Seller dari tahun 2013 hingga sekarang (24 mei 2015). Berdasarkan penjelasan-penjelasan tersebut, peneliti menganggap novel I Am Malala karya Christina Lamb tersebut layak untuk dianalisis berdasarkan tinjauan sosiologi sastra.

Fokus penelitian ini adalah konflik sosial pada tokoh utama dalam novel I Am Malala karya Christina Lamb dengan sosiologi sastra. Subfokus penelitian meliputi 1) struktur intrinsik dalam novel I Am Malala karya Christina Lamb, 2) bentuk-bentuk konflik sosial pada tokoh utama dalam novel I Am Malala karya Christina Lamb, 3) penyebab konflik sosial pada tokoh utama dalam novel $I$ Am Malala karya Christina Lamb , dan 4) penyelesaian konflik sosial pada tokoh utama dalam novel I Am Malala karya Christina Lamb.

Penelitian ini memiliki tujuan umum, yaitu untuk memperoleh deskripsi yang mendalam tentang konflik sosial pada tokoh utama dalam novel I Am Malala karya Christina Lamb dengan menggunakan sosiologi sastra. Tujuan khusus dalam penelitian ini meliputi: 1) dapat mengungkap struktur instrinsik dalam novel I Am Malala karya Christina Lamb 2) dapat mengungkap bentukbentuk konflik sosial pada tokoh utama dalam novel I Am Malala karya Christina Lamb, 3) dapat mengungkap penyebab konflik sosial pada tokoh utama dalam novel I Am Malala karyaChristina Lamb, dan 4) dapat mengungkap penyelesaian konflik sosial pada tokoh utama dalam novel I Am Malala karyaChristina Lamb.

Karya sastra bermutu akan selalu menampilkan unsur hiburan dan pelajaran secara seimbang. Unsur hiburan dan pelajaran disajikan secara kental dan menyatu semua unsur intrinsik dan unsur ektrinsik karya sastra yang bersangkutan.

Unsur-unsur intrinsik, seperti tema, alur/plot, tokoh dan penokohan, dan lain sebagainya adalah unsur-unsur yang 
membangun karya sastra dan ditopang oleh unsur-unsur ekstrinsik, seperti nilai religi, moral, riwayat pengarang, dan konflik. Kehidupan manusia tidak akan pernah terlepas dari konflik, baik konflik yang muncul dari kehidupan pribadi individu sendiri, atau pun konflik di luar individu itu sendiri.

Konflik dilatarbelakangi oleh perbedaan ciri-ciri yang dibawa individu dalam suatu interaksi. Perbedaanperbedaan tersebut diantaranya adalah menyangkut ciri fisik, kepandaian, pengetahuan, adat istiadat, keyakinan, dan lain sebagainya. Dengan dibawa sertanya ciri-ciri individual dalam interaksi sosial, konflik merupakan situasi yang wajar dalam setiap masyarakat dan tidak satu masyarakat pun yang tidak pernah mengalami konflik antar anggotanya atau dengan kelompok masyarakat lainnya, konflik hanya akan hilang bersamaan dengan hilangnya masyarakat itu sendiri.

Adanya novel mendapatkan ide-ide baru. Pembelajaran sastra yakni novel sebagai genre serta mempunyai fungsi yang dapat menumbuhkan rasa kepedulian terhadap karya dalam Kurikulum Berbasis Kompetensi membuka pencerahan baru agar siswa dapat lebih aktif dan konstruktif terhadap gejala atau situasi yang terjadi saat ini. Siswanto (2008: 157) mengatakan bahwa melalui pembelajaran sastra kita dapat mengembangkan peserta didik dalam hal keseimbangan antara spiritual, emosional, etika, logika, estetika, dan kinestika; pengembangan kecakapan hidup; belajar sepanjang hayat; serta pendidikan secara menyeluruh.

Soekanto

(2007:

98-99)

mendifinisikan konflik sebagai pertikaian atau pertentangan, yaitu "suatu proses sosial dimana individu atau kelompok berusaha untuk memenuhi tujuannya dengan jalan menantang pihak lawan yang disertai dengan ancaman atau kekerasan. Masalah yang timbul akibat hubungan sosial, interaksi sosial, atau adanya sesuatu yang bertentangan dalam interaksi antarindividu, sehingga menimbulkan friksi yang dapat menjurus pada kekerasan, kerusuhan, percekcokan, bahkan peperangan.

Penyebab Konflik sosial dapat terjadi karena adanya faktor-faktor yang menjadi penyebab konflik. Menurut Djatmiko (2008: 104) penyebab terjadinya konflik antara lain: a) Perbedaan tujuan, kebutuhan, nilai. b) Persaingan dan ambisi pribadi dalam hal promosi, kenaikan upah, yang dapat merusak semangat kerja, c) Stress, karena kecemasan atas kondisi keuangan, keluarga, benturan, perselisihan dengan orang lain, d) Perselisihan antar nilaI pribadi, dan e) Prasangka atas kesukuan, ras, agama, usia, sex. Sedangkan menurut Soekanto 
(2007: 99) konflik disebabkan karena adanya beberapa perbedaan dan perubahan, diantaranya adalah sebagai berikut: a) Perbedaan antara individuindividu, b) Perbedaan kebudayaan, c) Perbedaan kepentingan, dan d) Perubahan Sosial.

Menyelesaikan konflik yang baik adalah mencari akar permasalahan dari konflik tersebut sehingga dapat dicari titik penyelesaiannya (Setiadi dan Kolip, 2011:385). Gejala konflik sosial akan selesai jika akar penyebab konflik dapat ditiadakan tanpa menyisakan kondisi yang memendam antagonisme sehingga setiap saat bisa menyulut konflik baru.

Pada umumnya masyarakat memiliki sarana atau mekanisme untuk mengendalikan konflik di dalam tubuhnya. Beberapa ahli menyebutnya sebagai katup penyelamat, yaitu suatu mekanisme khusus yang dipakai untuk mempertahankan kelompok dari kemungkinan konflik. Secara umum ada empat macam bentuk penyelesaian konflik sosial, diantaranya: Konsiliasi, mediasi, Arbitrasi dan adjudication.

Jadi, penelitian ini diharapkan akan dapat memberikan kegunaan bagi kehidupan dan pengajaran sastra karena hasil dari proses analisis dari suatu karya sastra senantiasa akan memberikan manfaat terhadap masyarakat luas khususnya bagi para pembaca dan penikmat satra dalam memahami dinamika kehidupan kemasyarakatan yang diungkapkan pengarang lewat media kata atau bahasa.

\section{METODE PENELITIAN}

Secara umum, tujuan dari penelitian ini untuk mengkaji secara mendalam tentang: 1) Struktur intrinsik dalam novel I Am Malala Karya Christina Lamb yang menggambarkan konflik sosial. 2) Bentuk konflik sosial yang dialami tokoh utama dalam novel I Am Malala Karya Christina Lamb ditinjau dari segi sosiologi sastra. 3) Penyebab konflik sosial yang dialami tokoh utama dalam novel I Am Malala Karya Christina Lamb ditinjau dari segi sosiologi sastra, dan 4) Penyelesaian konflik sosial yang dialami tokoh utama dalam novel I Am Malala Karya Christina Lamb ditinjau dari segi sosiologi sastra.Penelitian ini tidak terikat dengan tempat dikarenakan penelitian ini menggunakan teknik analisis isi dengan intrumen penelitian adalah peneliti sendiri yang dibantu oleh tabel kerja.

Penelitian ini menggunakan metode kualitatif deskriptif dengan metode analisis isi menggunakan pendekatan sosiologi sastra, yaitu penelitian dilandaskan pada objek karya sastra yang dianalisis menggunakan teori sosiologi. Istilah ini pada dasarnya tidak 
berbeda pengertiannya dengan sosiosastra, pendekatan sosiologis, atau pendekatan sosiokultural terhadap sastra (Damono, 1984: 2). Pengkajian ini bertujuan untuk mengungkapkan berbagai informasi tentang bentuk-bentuk konflik sosial, penyebab terjadinya konflik sosial dan penyelesaian terhadap konflik sosial yang dialami oleh tokoh utama dengan pendeskripsian yang diteliti dengan menggambarkan secara detail sifat-sifat suatu hal (individu atau kelompok), keadaan, fenomena, dan tidak terbatas pada pengumpulan data melainkan meliputi analisis dan interpretasi data tersebut.

Data penelitian ini adalah tentang bentuk-bentuk konflik sosial, penyebab konflik sosial dan penyelesaian terhadap konflik sosial yang dialami tokoh utama yang berhasil dikumpulkan oleh peneliti yang akan dijadikan sebagai bahan dalam menganalisis. Data dalam penelitian ini adalah data kualitatif yang berupa katakata, ungkapan, dan kalimat dalam novel $I$ Am Malala karya Christina Lamb. Sedangkan sumber data dalam penelitian ini menggunakan data primer dan data sekunder.

Pengumpulan Data dilakukan dengan menempuh Langkah-langkah antara lain: (a) pengumpulan data kepustakaan, (b) pembacaan secara intensif dan berulang-ulang novel yang akan diteliti, (c) membuat catatan yang berupa abstraksi atau pendeskripsian setiap peristiwa yang merupakan unsur cerita dalam novel, (d) mengidentifikasi aspek-aspek yang tercantum dalam tujuan penelitian, dan (e) melakukan analisis dan interpretasi data.

Analisis data dilakukan secara deskriptif kualitatif dengan metode analisis isi. Menurut Mayring (2009: 108) bahwa analisis deskriptif kualitatif meliputi (1) penentuan materi, (2) analisis situasi tempat asal teks, (3) pengkarakteran materi, (4) penentuan arah analisis, (5) diferensiasi pertanyaan yang harus dijawab, dan (6) penyelesaian teknik analisis.

Adapun keabsahan data dalam penelitian ini penulis menggunakan derajat kepercayaan (kredibility). Sebagaimana menurut Lincon dalam Moleong (2013: 324) ada empat kriteria yang dapat dipakai untuk menjamin keterpercayaan hasil penelitian kualitatif, yaitu: derajat kepercayaan (credibility), keteralihan

(Transferability), kebergantungan, (dependability) dan kepastian (konfirmabilitas). 
HASIL PENELITIAN

DAN

PEMBAHASAN

Gambaran Umum tentang Latar

Penelitian

Latar penelitian ini berkaitan dengan fokus penelitian. Dalam penelitian ini difokuskan konflik sosial pada tokoh utama dalam novel I Am Malala karya Christina Lamb dengan sosiologi sastra. Sosiologi sastra dipilih karena isi novel $I$ Am Malala karya Christina Lamb berkaitan dengan ranah kehidupan sosial tokoh utama. Perihal konflik sosial tersebut difokuskan dalam penelitian ini dikarenakan tokoh utama, Malala, mengalami gejolak konflik dalam kehidupannya baik sebagai pribadi maupun sebagai pejuang pendidikan bagi anak-anak perempuan.

\section{Struktur Intrinsik dalam Novel I Am Malala karya Christina Lamb.}

Berdasarkan penelitian yang menjadi tema utama pada novel adalah "Education", kata pendidikan (education) terungkap bahwa Malala seorang gadis yang berdiri mengkampanyekan pendidikan untuk anak anak perempuan. Walaupun keluarganya berasal dari desa tertinggal namun melalui pendidikan dan kekuatan kepribadian membuat dia hidup lebih baik bagi keluarganya. Pendidikan telah menjadi hadiah yang besar baginya. Dia percaya bahwa kurangnya pendidikan adalah akar dari semua masalah Pakistan. Malala berbicara tentang ironi Taliban yang ingin guru perempuan dan dokter bagi perempuan namun tidak membiarkan anak-anak pergi ke sekolah untuk memenuhi syarat untuk pekerjaan tersebut.

Bila dikaitkan dengan wanita pada saat sekarang dimana dituntut untuk emansipasi, dimana wanita harus maju dan sejajar dengan laki-laki, maka novel ini sangat menginspirasi para wanita untuk berjuang dalam pendidikan agar derajat perempuan terangkat dan memiliki kesempatan yang sama dalam pendidikan sama seperti halnya laki-laki.

Berdasarkan penelitian alur dalam novel ini adalah alur campuran, karena mengandung alur maju dan alur mundur. Menurut Ulayya alur campuran yaitu alur yang diawali klimaks, kemudian melihat lagi masa lampau dan dilanjutkan sampai pada penyelesaian yang menceritakan banyak tokoh utama sehingga cerita yang satu belum selesai kembali ke awal untuk menceritakan tokoh yang lain. Tahapan: Klimaks $\rightarrow$ Peruwitan $\rightarrow$ Awal $\rightarrow$ Antiklimaks $\rightarrow$ Penyelesaian.

(http://www.slideshare.net/Anggin NU/alur)

Tokoh Utama dalam novel ini adalah: Malala Yousafzai, sedangkan tokoh tambahannya adalah: Bapaknya Ziauddin Yousafzai, dan Ibunya Tor 
Pekai. Tokoh Utama Malala dalam novel ini Malala berwajah khas suku pashtun pakistan dengan hidung mancung, rambut gelap, raut muka oval, bermata coklat sempurna dengan alis hitam yang tebal, bentuk bibir sempurna, dengan bulu mata yang lentik dan dia sering berkerudung merah, Malala bersama perjuangan ayahnya menjadi inspirasi dalam mengajak rekan rekannya untuk mengkampanyekan pendidikan di lingkungannya di lembah swat dan sekitarnya.

Dia adalah siswi yang paling terkenal di dunia. Dia mendapat panggilan Skyped dari Sekretaris Jenderal PBB, minum teh bersama Angelina Jolie, dan Madonna telah mendedikasikan sebuah lagu untuknya. Pada ulang tahunnya yang ke-16 pada bulan Juli fotonya diproyeksikan di Jembatan Brooklyn di New York, ia mendapat sambutan meriah di PBB, dan Beyonce mengirim Instagram. IPod-nya adalah hadiah dari Bono, potret dirinya tergantung di National Portrait Gallery dan dia adalah orang termuda yang mendapat hadiah Nobel perdamaian. "She's the most famous schoolgirl in the world" (http://christinalamb.net/articles/my-yearwith-Malala.html).

Tokoh Utama Malala menjadi salah satu korban yang selamat, seorang saksi terhadap kekacauan lembah swat setelah di kuasai militan taliban, menjadi seorang tokoh pejuang pendidikan yang pernah coba di bungkam oleh taliban, tetapi selamat dan meneruskan perjuangannya di inggris sebagai seorang siswa dan sebagai seorang aktivis pendidikan sampai puncak kesuksesan perjalanannya Malala Meraih Penghargaan menjadi Penerima Hadiah Nobel Perdamaian pada 10 Desember 2014. Malala seorang gadis yang memiliki perwatakan senang berkumpul dan bercanda bersama sahabat sahabatnya seperti Moniba dan gether, suka bergosip dan suka humor, perhatian dengan lingkungan, menyayangi saudara saudaranya, pemikir, suka bergaul dan berkumpul, rajin belajar, rajin bersekolah, bercita cita menjadi politisi, aktif mengkampanyekan hak pendidikan untuk para gadis, seorang juru kampanye untuk pendidikan perempuan.

Tokoh Tambahan ayahnya Ziauddin Yousafzai adalah seorang perintis sekolah dan aktifis pendidikan di daerahnya dan menjadi simbol perjuangan pendidikan di sebuah negeri yang kacau sebagai akibat dari perang dan kekerasan antara Militan, Taliban dan militer di Negara pakistan. Dalam novel ini tokoh utama Ziauddin Yousafzai menjadi inspirasi dalam mengajak rekan rekannya untuk merintis sekolah dan mengkampanyekan pendidikan di 
lingkungannya di lembah Swat dan sekitarnya. memiliki perwatakan gagap masa kecil, seorang pria yang begitu mencintai kata-kata dan puisi, suka menolong ketika Istri kepala sekolah jatuh sakit, ayahnya menyumbangkan darah untuk membantu menyelamatkannya, bisa marah terutama apabila di peras dan di tertawakan di depan orang, ingin orang tuanya bangga dan dia juga menyukai pidato, pandai berpidato, suka membaca buku, ayahnya sangat sayang terhadap ibunya.

Tokoh tambahan ibunya mulai sekolah ketika berusia enam, Dia tidak biasa tinggal di rumah di desa karena ia memiliki ayah dan saudara-saudara yang mendorongnya untuk pergi ke sekolah. Dia adalah satu-satunya gadis dalam kelas anak laki-laki. Dia bangga membawa tas dengan buku ke sekolah dan mengaku dia adalah lebih pandai dari anak laki-laki. Ibunya memiliki perwatakan khawatir terhadap keselamatan Malala, dia tidak bisa membaca, ibunya tidak pernah pergi dari lembah swat kemanapun, ibunya suka memberi makan burung burung.

Perwatakan lainnya adalah bahwa ibunya bisa memasak, ibunya menginginkan anak laki-laki, ibunya sangat cantik, ibunya sangat soleh dan dia sholat lima kali sehari, ibunya iri terhadap sepupunya yang tidak sekolah dan tinggal dirumah, ibunya memiliki kebijaksanaan walaupun dia tidak sekolah.

Novel ini berlatarkan negara Pakistan kota mingora, lembah swat, shangla, karachi, islamabad, lahore, bajaur, waziristan, shahpur, malakand, deri dan quetta. Sedangkan latar peristiwa diluar negeri terjadi di Afganistan, Amerika dan Inggris dengan nama kotanya washington, london, birmingham, adapun latar yang di alami tokoh utama malala adalah lahir dan di besarkan di lembah swat di pakistan utara, dengan pusat kotanya yang bernama Mingora. latar waktu peristiwa terjadi mulai dari tahun sekitar tahun 1977 hingga tahun 2012. dengan latar situasi: (1) Pengambaran kilas balik sejarah berdirinya pakistan, (2) Penggambaran latar kehidupan tradisional suku pashtun, (3) Kudeta jenderal Zia dan berkembangnya regim Zia, (4) Peristiwa invansi rusia ke afganistan, (5) Awal berkembangnya taliban,

Berkembangnya dominasi taliban, (7) Konflik antara taliban dengan penduduk, (8) Konflik antara taliban dengan tokoh utama, (9) Pertempuran antara taliban dan militer, (10) Pengungsian penduduk dari lokasi pertempuran, (11) Setelah taliban kalah, (12) Penduduk kembali dari pengungsian, (13) Pemulihan pasca pertempuran, (14) Konflik antara militer dengan sisa taliban, (15) Terjadinya 
penembakan terhadap tokoh utama, (16)

Darurat penyelamatan tokoh utama di rumah sakit di pakistan,

Penyelamatan tokoh utama di rumah sakit queen elizabet birmingham inggris, dan (18) Pemulihan dan memasuki kehidupan kedua setelah selamat di birmingham inggris.

\section{Bentuk-bentuk Konflik Sosial Pada Tokoh Utama Dalam Novel I Am Malala Karya Christina Lamb.}

Berdasarkan temuan konflik sosial pada tokoh dalam novel I Am Malala karya Christina Lamb yang ditinjau dari aspek sosiologi sastra. terdapat: (1) Bentuk konflik sosial yang dialami tokoh, (2) Penyebab konflik sosial yang dialami tokoh, dan (3) Penyelesaian konflik sosial yang dialami tokoh. Bentuk-Bentuk Konflik Sosial Pada Tokoh Utama Dalam Novel ini meliputi: Konflik Gender, Konflik Ras dan Antar Suku, Konflik Antar Umat Agama, Konflik Antar Golongan, Konflik Kepentingan, Konflik Pribadi, Konflik Kelas Sosial, dan Konflik Antar Negara/Bangsa. Konflik yang paling menonjol dalam novel ini adalah Konflik tentang gender.

Bentuk konflik gender yang terjadi bahwa Malala adalah anak perempuan di negeri yang menembakkan senapan untuk merayakan kelahiran anak laki-laki, sementara anak perempuan disembunyikan di balik tirai, peranan mereka dalam hidup hanyalah menyiapkan makanan dan melahirkan, bagi sebagian besar orang Pashtun, hari tampak muram ketika seorang anak perempuan lahir.

Bentuk konflik gender lainnya adalah Ibu dan teman-temannya marah karena tidak boleh pergi berbelanja, terutama pada hari-hari sebelum liburan Idul Fitri. Militan melarang perempuan tidak boleh keluar tanpa pendamping. Bentuk konflik gender lainnya adalah Di bawah rezim zia kehidupan bagi perempuan di Pakistan menjadi sangat terbatas. Jinnah mengatakan, 'Tidak ada Perjuangan laki laki yang dapat pernah berhasil tanpa berdampingan dengan wanita yang berpartisipasi. Ada dua kekuatan di dunia; satu adalah pedang dan yang lainnya adalah pena. Ada kekuatan ketiga lebih kuat dari keduanya, yaitu wanita. Perempuan mereka mengenakan celana baggy bukan celana pendek, dan perempuan dilarang memainkan olahraga sama sekali.

Bentuk konflik gender lainnya adalah semua orang di Swat gembira, apalagi Malala karena itu berarti sekolah akan buka kembali dengan benar. Taliban mengatakan anak perempuan bisa pergi ke sekolah setelah kesepakatan perdamaian, tetapi mereka harus terselubung dan tertutup. Mereka mengatakan "OK 
Pembahasan

diatas

menggambarkan konflik sosial berbentuk konflik gender. Kata ,gender dapat diartikan sebagai perbedaan peran, fungsi, status dan tanggungjawab pada laki-laki dan perempuan sebagai hasil dari bentukan (konstruksi) sosial budaya yang tertanam lewat proses sosialisasi dari satu generasi ke generasi berikutnya (Puspitawati, 2012: 1) Dengan demikian gender adalah hasil kesepakatan antar manusia yang tidak bersifat kodrati. Oleh karenanya gender bervariasi dari satu tempat ke tempat lain dan dari satu waktu ke waktu berikutnya. Gender tidak bersifat kodrati, dapat berubah dan dapat dipertukarkan pada manusia satu ke manusia lainnya tergantung waktu dan budaya setempat

Perbedaan gender sesungguhnya tidaklah menjadi masalah sepanjang tidak melahirkan ketidakadilan gender. Namun yang menjadi persoalan, ternyata perbedaan gender menimbulkan ketidakadilan baik bagi laki-laki maupun perempuan. Banyak kaum perempuan yang mengalami ketidakadilan gender yang merupakan hak mereka dalam memposisikan sama dengan laki-laki. Hal ini terbukti bahwa kaum laki-laki khususnya yang masih berada dalam lingkungan patriarkal, mereka lebih banyak berperan sentral dalam segala urusan khususnya dalam memilih jalan hidup yang salah satunya adalah tentang profesi. Kaum laki-laki bebas memilih sendiri profesi yang diinginkan tanpa ada orang lain disekitarnya yang peduli. Terlepas dari itu semua kaum laki-laki juga ada yang mendapat perlakuan tidak adil dari pihak perempuan. Ada juga kaum laki-laki yang merasa tidak mendapatkan haknya. Karena konsep gender adalah sesuatu yang bisa berubah dari waktu ke waktu, sesuatu yang bisa bertukar bukan sesuatu yang menjadi kodrat dan tidak bisa dipertukarkan.

Perbedaan biologis ini menjadi indikator kepantasan dalam berperilaku yang akhirnya berujung pada pembatasan hak, akses, partisipasi, kontrol dan menikmati manfaat dari sumberdaya dan informasi. Akhirnya tuntutan peran, tugas, kedudukan dan kewajiban yang pantas dilakukan oleh laki-laki atau perempuan dan yang tidak pantas dilakukan oleh lakilaki atau perempuan sangat bervariasi dari masyarakat satu ke masyarakat lainnya. Ada sebagian masyarakat yang sangat kaku membatasi peran yang pantas dilakukan baik oleh laki-laki maupun perempuan, misalnya tabu bagi seorang laki-laki masuk ke dapur atau mengendong anaknya di depan umum dan tabu bagi seorang perempuan untuk sering keluar rumah untuk bekerja. Namun demikian, ada juga sebagian masyarakat yang fleksibel dalam memperbolehkan 
laki-laki dan perempuan melakukan aktivitas sehari-hari, misalnya perempuan diperbolehkan bekerja sebagai kuli bangunan sampai naik ke atap rumah atau memanjat pohon kelapa, sedangkan lakilaki sebagian besar menyabung ayam

Dalam kehidupan nyata gender sudah tidak menjadi momok lagi, karena sekarang dengan adanya emansipasi wanita, perempuan sudah diberikan kesempatan yang sama dengan laki-laki baik dalam persamaan hak, maupun kesempatan dalam berkarya untuk mencapai apa yang dicita-citakan.

\section{Penyebab Konflik Sosial Pada Tokoh} Utama Dalam Novel I Am Malala Karya Christina Lamb.

Penyebab konflik sosial yang dialami tokoh pada novel Iam Malala disebabkan karena adanya beberapa perbedaan dan perubahan, diantaranya adalah sebagai berikut: (1) Perbedaan antara individu-individu. Perbedaan pendirian dan perasaan mungkin akan melahirkan bentrokan antara mereka, (2) Perbedaan kebudayaan. Seseorang secara sadar maupun tidak sadar, sedikit banyak akan terpengaruh oleh pola-pola pemikiran dan pola-pola pendirian dari kelompoknya. Selanjutnya, keadaan tersebut dapat menyebabkan terjadinya pertentangan antara kelompok manusia. (3) Perbedaan kepentingan. Perbedaan kepentingan antar individu maupun kelompok merupakan sumber lain dari pertentangan. Wujud dari kepentingan bisa bermacam-macam; ada kepentingan ekonomi, politik dan lain sebagainya, dan (4) Perubahan Sosial. Perubahan sosial yang berlangsung dengan cepat untuk sementara waktu akan mengubah nilainilai yang sudah ada dalam masyarakat. Hal tersebut akan menyebabkan terjadinya golongan-golongan yang berbeda pendiriannya, mengenai reorganisasi sistem nilai. Sebagaimana diketahui perubahan sosial mengakibatkan terjadinya disorganisasi pada struktur.

Pada novel I Am Malala ini pembahasan penyebab konflik yang disebakan perbedaan tradisi dan kebudayaan paling menonjol dibandingkan penyebab yang lainnya, yaitu: contohnya adalah ketika ibunya Malala pergi berbelanja ke Cheena Bazaar dengan sepupunya seorang Talib menyapa ketika melihat mereka memakai syal tapi tidak dengan burqa dengan mengatakan mereka akan menangkapnya,

Pembahasan penyebab perbedaan tradisi dan kebudayaan lainnya terjadi pada saat Presiden memberi pengarahan pada dokter. Kemudian dia datang untuk melihat Malala bersama putri bungsunya Asifa, yang beberapa tahun lebih tua dari Malala. Mereka membawa buket bunga, dia menyentuh kepalanya, itu merupakan 
tradisi mereka, tapi ayahnya khawatir karena hanya kulit, dan tidak ada tulang untuk melindungi otak Malala, dan kepalanya di bawah selendang itu cekung. Setelah itu presiden duduk dengan ayahnya, yang mengatakan kepadanya bahwa mereka beruntung telah dibawa ke Inggris. "Dia mungkin selamat di Pakistan tapi dia tidak memiliki rehabilitasi yang baik dan khawatir akan cacat, 'dia berkata. sekarang senyumnya akan kembali.

\section{Penyelesaian Konflik Sosial Pada Tokoh Utama Dalam Novel I Am Malala Karya Christina Lamb.}

Pembahasan penyebab perbedaan tradisi dan kebudayaan lainnya adalah tradisi untuk pengantin menerima furniture atau mungkin kulkas dari keluarganya dan beberapa emas dari keluarga pengantin pria. Kakeknya tidak membeli emas sehingga ayahnya harus meminjam lebih banyak uang untuk membeli gelang. Setelah pernikahan ibunya pindah dengan kakeknya dan pamannya. Ayahnya kembali ke desa setiap dua atau tiga minggu untuk menengoknya. Rencananya adalah untuk mendapatkan sekolah, setelah berhasil, dia mengirim untuk istrinya. Tapi Baba terus mengeluh tentang pendapatan yang terkuras dan itu membuat hidup ibunya sengsara. Dia memiliki sedikit uang dari sehingga mereka gunakan untuk menyewa sebuah van dan mereka pindah ke Mingora. Mereka tidak tahu bagaimana mereka akan mengelola. mereka hanya tahu ayahnya tidak ingin di sana, "kata ayahnya. 'Pada saat itu mereka tidak bahagia dengan keluarga mereka, tapi kemudian bersyukur karena itu membuat mereka lebih mandiri.

Pembahasan penyebab perbedaan tradisi dan kebudayaan lainnya adalah kadang-kadang ada pernikahan dengan pesta besar yang berlangsung selama beberapa hari dan meninggalkan keluarga dalam bangkrut atau berhutang. Pengantin akan mengenakan pakaian yang indah dan akan terbungkus emas, kalung dan gelang yang diberikan oleh kedua belah pihak keluarga. Malala membaca bahwa Benazir Bhutto bersikeras memakai gelang bukan emas di pernikahannya untuk memberi contoh tetapi tradisi menghiasi pengantin masih berlanjut. Kadang-kadang sebuah peti mati kayu lapis akan datang dari salah satu tambang. Para wanita akan berkumpul di rumah istri orang mati dan ratapannya mengerikan dan menggema disekitar lembah, yang membuat Malala merinding.

Pembahasan penyebab perbedaan tradisi dan kebudayaan lainnya yaitu ketika Malala lahir mereka sangat miskin. Ayahnya dan seorang teman telah mendirikan sekolah pertama mereka dan mereka tinggal di sebuah gubuk kumuh 
dengan dua kamar bersebrangan dengan sekolah. Malala tidur dengan ibu dan ayahnya dalam satu ruang dan ruang yang lain untuk tamu. Mereka tidak punya kamar mandi atau dapur, dan ibunya memasak dengan api dari kayu di tanah dan mencuci pakaian dengan air keran dari sekolah. rumah selalu penuh pengunjung dari desa. Tradisi menerima dan menghormati tamu adalah bagian penting dari budaya Pashtun.

Pembahasan penyebab perbedaan tradisi dan kebudayaan lainnya yaitu situasi menjadi mengerikan bahwa ayahnya terpaksa menjual gelang emas. Dalam budaya mereka perhiasan pernikahan adalah ikatan antara pasangan. Seringkali wanita menjual perhiasan mereka untuk membantu mengatur suami mereka dalam bisnis atau untuk membayar perjalanan mereka pergi ke luar negeri. Ibunya sudah menawari gelang untuk membayar keponakan ayahnya untuk sekolah ke perguruan tinggi, yang ayahnya terlanjur berjanji untuk mendanai untungnya, sepupu ayahnya Jehan Sher Khan telah mengambil alih dan dia tidak menyadari gelangnya hanya cukup untuk sebagian pembayaran. Dia kemudian marah ketika ia mengetahui bahwa ayahnya tidak mendapatkan cukup harga untuk mereka.

Konflik yang disebabkan oleh perbedaan budaya ini pada kehidupan nyata sering terjadi didaerah-daerah yang perbedaan kebudayaannya sangat mencolok, dan biasanya tingkat pendidikan nya rendah. Akhirnya memicu ketegangan diantara dua pihak yang berselisih atau bertikai.

\section{Penyelesaian Konflik Sosial Pada Tokoh Utama Dalam Novel I Am Malala Karya Christina Lamb.}

Sementara penyelesaian konflik sosial yang dialami tokoh adalah dengan konsiliasi, mediasi, Arbitrase, dan Adjudikasi. Yang paling bagus adalah penyelesaian konflik dengan cara mediasi. Karena mediasi adalah negosiasi antara pihak yang berkonflik dan melibatkan pihak ketiga dengan tujuan membantu demi tercapai penyelesaian yang bersifat kompromi.

Negosiasi dan mediator merupakan salah satu cara dalam penyelesaian sengketa yang dikenal dalam hukum perdata dan hukum bisnis. Mediasi menurut Nolan Haley (dikutip oleh Raharjo, 2008:196) adalah " a short term structured ted, partipatory invention process. Disputing parties work with a neutral third party, the mediator, to reach mutually aceeptable agreement".

Apabila proses mediasi tersebut berjalan dengan baik dan menghasilkan kesepakatan, maka perkara pidana tersebut selesai. 
Sebaliknya, jika mediasi gagal, maka proses selanjutnya adalah mengikuti proses penyelesaian perkara pidana melalui jalur litigasi. Hal ini berarti perkara dilanjutkan sampai ke persidangan di muka hakim. Hakimlah yang akan memutuskan bersalah atau tidaknya si pelaku kejahatan. Untuk menjamin kepastian hukum, sebaiknya kesepakatan yang dicapai oleh kedua belah pihak baik di luar maupun di dalam peradilan pidana dibuatkan surat perjanjian atau akta notaris sebagai bukti yang kuat. Hal ini untuk menghindari penyangkalan dari pelaku pelaku kejahatan yang tak mau melaksanakan hasil kesepakatan. Dengan bukti itu, pelaku kejahatan tak dapat mengelak.

Berdasarkan penelitian dalam novel "I Am Malala", Karya Christina Lamb, penyajian temuan data konflik sosial yang di selesaikan dengan cara mediasi yaitu: pada kasus bagaimana Malala akan dipindahkan dan pembayaran pengobatan, siapa yang harus membayar, akhirnya diselesaikan dengan mediasi Dr Javid menyarankan mengambil tawaran dari Royal Air Force karena mereka digunakan untuk mengangkut tentara yang terluka dari Afghanistan, tapi Kayani menolak. Dia memanggil Dr Javid untuk pertemuan larut malam di rumahnya dan menjelaskan, bahwa dia tidak ingin ada militer asing yang terlibat.
Sudah terlalu banyak teori konspirasi beredar tentang penembakan Malala, orang-orang mengatakan bahwa Malala adalah seorang agen CIA, dan kepala militer tidak mau. serta meninggalkan Dr Javid dalam posisi yang sulit. Pemerintah Inggris telah menawarkan bantuan tetapi diperlukan permintaan resmi dari pemerintah Pakistan. Untungnya pada saat itu keluarga penguasa dari Uni Emirat Arab mengambil alih. Mereka menawarkan jet pribadi mereka, yang dilengkapi rumah sakit dalam pesawat. Malala akan diterbangkan dari Pakistan untuk pertama kalinya dalam hidup di dini hari Senin, 15 Oktober. Bahwa terjadi upaya penyelesaian terhadap persoalan pengiriman Malala ke inggris dengan dr javid sebagai mediator antara Malala, dengan pemerintah, militer, inggris dan UEA.

Kemudian penyelesaian konflik lainnya adalah ketika ada satu masalah besar dua kakek mereka tidak akur. Jadi, ketika ayahnya menyatakan keinginannya untuk melamar ibunya, Tor Pekai, jelas keluarga dari kedua belah pihak tidak menyambut perkawinan itu. Kakek dari ayahnya sendiri mengatakan terserah kepada ayahnya, dan dia setuju untuk mengirim seorang tukang cukur sebagai utusan. itu cara tradisional mereka, orang Pashtun, dalam melakukan hal tersebut. Malik Janser Khan menolak lamaran itu 
tapi ayahnya adalah lelaki yang keras kepala dan dia membujuk kakeknya untuk mengutus tukang cukur lagi. Hujra milik Janser Khan adalah tempat berkumpul orang-orang untuk bicara politik, dan ayahnya sering berada di sama, jadi mereka saling mengenal. Janser Khan menyuruh ayahnya menunggu selama sembilan bulan, tapi akhirnya dia setuju, bahwa terungkap telah terjadi upaya mediasi terhadap kedua kakeknya dalam persoalan perjodohan antara ayahnya dan ibunya.

Penyelesaian konflik dengan cara mediasi dilakukan apabila kedua pihak yang berkonflik sepakat untuk menunjuk pihak ketiga sebagai mediator. Pihak ketiga ini akan memberikan pemikiran atau nasihat-nasihatnya tentang cara terbaik dalam menyelesaikan pertentangan mereka. Sekalipun pemikiran atau nasihat pihat ketiga tersebut tidak mengikat, cara penyelesaian ini kadang menghasilkan penyelesaian yang cukup efektif. Pada kehidupan nyata mediasi ini sangat dibutuhkan manakala konflik sudah tidak bisa diselesaikan, sehingga perlu orang pihak ketiga yang dapat menjembatani kedua belah pihak yang sedang berkonflik agar cepat selesai.

\section{SIMPULAN DAN REKOMENDASI}

Simpulan yang dapat di tarik dari penelitian konflik sosial pada tokoh utama dalam novel "I Am Malala ", (suatu penelitian sosiologi sastra) adalah pengarang secara jelas dan rinci dalam novel tokoh bernama Malala sebagai tokoh utama, disamping malala sebagai tokoh utama pengarang juga menggambarkan tokoh tambahan, tokoh protagonist, tokoh antagonis. Adapun Malala sebagai tokoh utama dan 2 tokoh tambahan tersebut memiliki perwatakan baik dan juga perwatakan buruk, perwatakan buruk sangat sedikit sehingga tidak terlihat dan tertutupi perwatakan baiknya. Konflik sosial pada novel ini dibahas dari mulai bentuk-bentuk konflik, penyebab konflik, dan penyelesaian konflik.

Novel ini sangat bagus untuk siswa SMA (Sekolah Menegah Atas) karena banyak pendidikan karakter yang dapat di teladani dari diri sosok Malala, sebagai pejuang yang memperjuangkan pendidikan dan gender wanita.

Kepada pengajar mata pelajaran bahasa dan sastra Indonesia agar dapat menggunakan novel I Am Malala sebagai bahan ajar dan salah satu media dalam pengajaran bahasa dan sastra Indonesia. Salah satu media efektif dalam penanaman nilai-nilai religius kepada siswa adalah dengan media sastra salah satunya adalah novel. Novel secara tersirat dan tersurat dapat menyampaikan amanat berupa hal-hal positif yang bisa 
diambil hikmahnya. Novel "I Am Malala"

dapat digunakan sebagai salah satu alternatif untuk menambah minat serta kemauan belajar sastra dalam mempelajari satra lebih mendalam. adapun novel dapat dijadikan acuan untuk menelaah sastra karena isi novel tersebut lekat dengan kehidupan masyrakat. walaupun berisi tentang konflik sosial namun novel sarat dengan nilai positif.

\section{DAFTAR PUSTAKA}

Bambang Kaswanti, Purwo. Bulir-Bulir Sastra dan Bahasa Pembaharuan Pengajaran.

Yogyakarta: Kanisius, 1991.

Damono, Sapardi Djoko, Sosiologi Sastra Sebuah Pengantar Ringkas. Jakarta: Pusat Pembinaan dan Pengembangan Bahasa, Departemen Pendidikan dan kebudayaan, 1984.

Djatmiko, Yayat Hayati. Perilaku Organisasi. Bandung: Alfabeta, 2008.

Mayring, dalam Titscher, Mayer, Wodak, Velter, diterjemahkan oleh Gazali $\mathrm{dkk}$, Metode Analisis teks dan
Wacana. Yogyakarta: Pustaka Pelajar, 2009.

Maleong, Lexy. Metodelogi Penelitian Kualitatif. Bandung: PT Remaja Rosada Karya, 2013.

Puspitawati, Herien. konsep teori dan analisis gender. Bogor: PT IPB press, 2012.

Raharjo, Agus. Mediasi Sebagai Basis dalam Penyelesaian Perkara Pidana. Mimbar Hukum. Volume 20, Nomor 1, Februari 2008, Halaman 1-191.

Setiadi, Elly M. Setiadi dan Usman Kolip, Pengantar Sosiologi: Pemahaman Fakta dan Gejala Permasalahan Sosial: Teori, Aplikasi dan Pemecahannya. Jakarta: Kencana, 2011.

Soejono, Soekanto. Sosiologi Suatu Pengantar. Jakarta: Rajawali Press, 2007.

http://christinalamb.net/articles/my-yearwith-Malala.html di akses 24 juni 2015

Ulayya, $\begin{gathered}\text { Anggin } \\ \text { Nisrina, }\end{gathered}$
$\frac{\text { http://www.slideshare.net/Anggin }}{\text { NU/alur-cerpen? } \quad \text { related }=1}$,
diakses 2 Oktober, 2015.

